Article

\title{
The Role of Platelet-Derived ADP and ATP in Promoting Pancreatic Cancer Cell Survival and Gemcitabine Resistance
}

\author{
Omar Elaskalani ${ }^{1}$, Marco Falasca ${ }^{2}$ (D), Niamh Moran ${ }^{3}$, Michael C. Berndt ${ }^{4}$ and Pat Metharom ${ }^{5, *}$ \\ 1 Platelet Research Laboratory, School of Biomedical Sciences, Curtin Health and Innovation Research \\ Institute, Faculty of Health Sciences, Curtin University, Bentley, WA 6102, Australia; \\ omar.elaskalani@postgrad.curtin.edu.au \\ 2 Metabolic Signalling Group, School of Biomedical Sciences, Curtin Health Innovation Research Institute, \\ Curtin University, Bentley, WA 6102, Australia; marco.falasca@curtin.edu.au \\ 3 Molecular and Cellular Therapeutics, Royal College of Surgeons in Ireland, Dublin 2, Ireland; \\ nmoran@rcsi.ie \\ 4 Faculty of Health Sciences, Curtin University, Bentley, WA 6102, Australia; m.berndt@curtin.edu.au \\ 5 Platelet Research Laboratory, Curtin Health and Innovation Research Institute, Faculty of Health Sciences, \\ Curtin University, Bentley, WA 6102, Australia \\ * Correspondence: pat.metharom@curtin.edu.au; Tel.: +61-8-9266-9271
}

Received: 23 August 2017; Accepted: 19 October 2017; Published: 24 October 2017

\begin{abstract}
Platelets have been demonstrated to be vital in cancer epithelial-mesenchymal transition (EMT), an important step in metastasis. Markers of EMT are associated with chemotherapy resistance. However, the association between the development of chemoresistance, EMT, and the contribution of platelets to the process, is still unclear. Here we report that platelets regulate the expression of (1) human equilibrative nucleoside transporter 1 (hENT1) and (2) cytidine deaminase (CDD), markers of gemcitabine resistance in pancreatic cancer. Human ENT1 (hENT1) is known to enable cellular uptake of gemcitabine while CDD deactivates gemcitabine. Knockdown experiments demonstrate that Slug, a mesenchymal transcriptional factor known to be upregulated during EMT, regulates the expression of hENT1 and CDD. Furthermore, we demonstrate that platelet-derived ADP and ATP regulate Slug and CDD expression in pancreatic cancer cells. Finally, we demonstrate that pancreatic cancer cells express the purinergic receptor $\mathrm{P}_{2} \mathrm{Y}_{12}$, an ADP receptor found mainly on platelets. Thus ticagrelor, a P2 $\mathrm{Y}_{12}$ inhibitor, was used to examine the potential therapeutic effect of an ADP receptor antagonist on cancer cells. Our data indicate that ticagrelor negated the survival signals initiated in cancer cells by platelet-derived ADP and ATP. In conclusion, our results demonstrate a novel role of platelets in modulating chemoresistance in pancreatic cancer. Moreover, we propose ADP/ATP receptors as additional potential drug targets for treatment of pancreatic cancer.
\end{abstract}

Keywords: platelets; ADP; ATP; pancreatic cancer; gemcitabine

\section{Introduction}

Despite remarkable advancements in our understanding of cancer development and progression, pancreatic ductal adenocarcinoma (PDAC) continues to be one of the most aggressive types of cancer, with a mortality rate that has not changed for the last 50 years. In addition to relatively late stage symptoms and high metastasis, chemotherapy resistance contributes significantly to increased mortality in PDAC [1]. Hypercoagulable disorders often characterise people living with PDAC, marked particularly with an increased risk of venous thromboembolism (VTE) [2]. The association of PDAC with thrombotic events thus suggests a close interplay between cancer and platelets, the key player in haemostasis and thrombosis. 
Within the blood compartment, tumour cells can form aggregates with platelets to avoid natural killer cell-mediated cytotoxicity [3-5]. PDAC cells can induce platelet activation and aggregation [6]. Once activated, platelets release growth factors and angiogenic factors which contribute to cancer progression [7-9]. Platelets through direct contact or release of Transforming growth factor beta 1 (TGF $\beta 1$ ) can activate epithelial-mesenchymal transition (EMT) in tumour cells, an important step in cancer metastasis $[10,11]$. EMT is a phenotypic alteration in cancer cells towards a more metastatic phenotype characterised by elongated shape and advanced ability to invade and migrate to distant organs, associated with a change in the level of several adhesion proteins and transcriptional factors. For example, Slug, Snail, Twist and Zinc finger E-box-binding homeobox 1 (Zeb-1) are described as mesenchymal transcriptional factors. Upregulation of some or all these factors may predispose cells to a mesenchymal phenotype [12]. Recently it has been shown that EMT may play a role in cancer progression other than by promoting metastasis. For example, Snail and Slug have been associated with chemotherapy resistance $[13,14]$. Moreover, gemcitabine-resistant PDAC cells display an EMT signature [15], while deletion of the EMT program in a pancreatic cancer mouse model enhanced gemcitabine sensitivity [16].

Gemcitabine is a prodrug cytidine analogue that is clinically used to manage PDAC. Like most cytidine analogues, the activity of gemcitabine is dependent on its cellular uptake, drug activation and deactivation rates. Gemcitabine is a hydrophilic drug. Therefore penetration through the lipid bilayer of the plasma membrane is a crucial step in gemcitabine-mediated cytotoxicity. The human nucleoside transporters mediate cellular uptake of gemcitabine. Deoxycytidine kinase mediates the phosphorylation-dependent activation of gemcitabine, while cytidine deaminase (CDD) catalyses gemcitabine deactivation [17-19]. Indeed, overexpression of hENT1 was associated with enhanced gemcitabine response while downregulation of CDD reduced gemcitabine resistance [20,21]. CDD expression is relatively high in some organs like liver [22], where most drugs passage on their transit to the target organ.

In this study, we have explored if platelets can drive gemcitabine resistance in PDAC cells. To investigate this, we exposed cancer cells to platelets or the releasate from aggregated platelets and examined the level of several proteins that are known to impart gemcitabine resistance in PDAC (Slug, CDD, hENT1) and the phosphorylated level of the survival signalling molecules such as Protein kinase B (also known as Akt) and Extracellular signal-regulated kinase (Erk). We also found that the platelet-derived nucleotides, ADP and ATP, are the main soluble mediators that drive gemcitabine resistance, which is completely blocked by ticagrelor, an ADP $\mathrm{P}_{2} \mathrm{Y}_{12}$ receptor antagonist, and that the $\mathrm{P}_{2} \mathrm{Y}_{12}$ receptor antagonist is expressed not only on platelets but also on PDAC cells.

\section{Results}

\subsection{Platelet Releasate Promotes Proliferation and Survival Signals in PDAC Cells Challenged with Gemcitabine}

High platelet count is associated with chemotherapy resistance and poor prognosis [23]. It is known that activated platelets release a variety of growth factors that support cancer cell proliferation and survival [24-26]. In order to address if platelets also enable PDAC cells to survive the antiproliferative effect of gemcitabine, platelet releasate isolated from collagen-related peptide (CRP)-aggregated platelets was incubated with cancer cells at increasing concentrations of gemcitabine $(0-100 \mu \mathrm{M})$ for $72 \mathrm{~h}$. As shown in Figure 1A,B, platelet releasate induced a significant increase in proliferation in PDAC cell lines, AsPC- 1 and BxPC-3, despite gemcitabine challenge ( $n \geq 4$; AsPC- 1 , $p<0.05$ and BxPC-3, $p<0.05$ at $10 \mu \mathrm{M}$ and $1 \mu \mathrm{M}$ gemcitabine, respectively).

Next, we examined if platelet releasate can initiate survival signals in cancer cells challenged with gemcitabine. AsPC-1 cells are considered gemcitabine-resistant, while BxPC-3 cells are gemcitabine sensitive. Therefore, two different concentrations of gemcitabine were used with the two cell lines. AsPC- 1 and BxPC-3 cells were incubated with platelet releasate \pm gemcitabine $(25 \mu \mathrm{M}$ and $10 \mu \mathrm{M}$, respectively) for $2 \mathrm{~h}$ in Roswell Park Memorial Institute (RPMI) serum-free medium. 
As shown in Figure 1C,D, platelet releasate triggered a significant upregulation of phosphorylation of the survival signalling molecules, p-Erk and p-Akt, in both AsPC-1 and BxPC-3 cells, which was unaffected by the presence of gemcitabine.
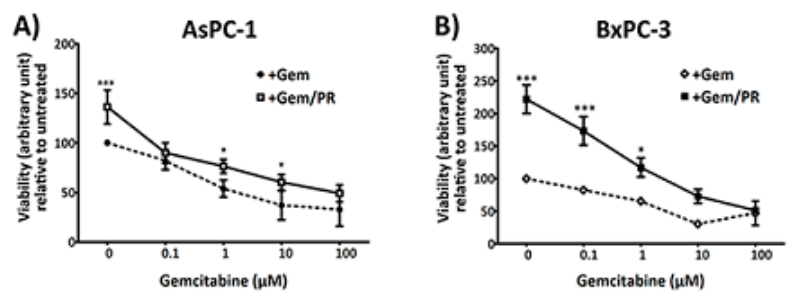

C)

AsPC-1
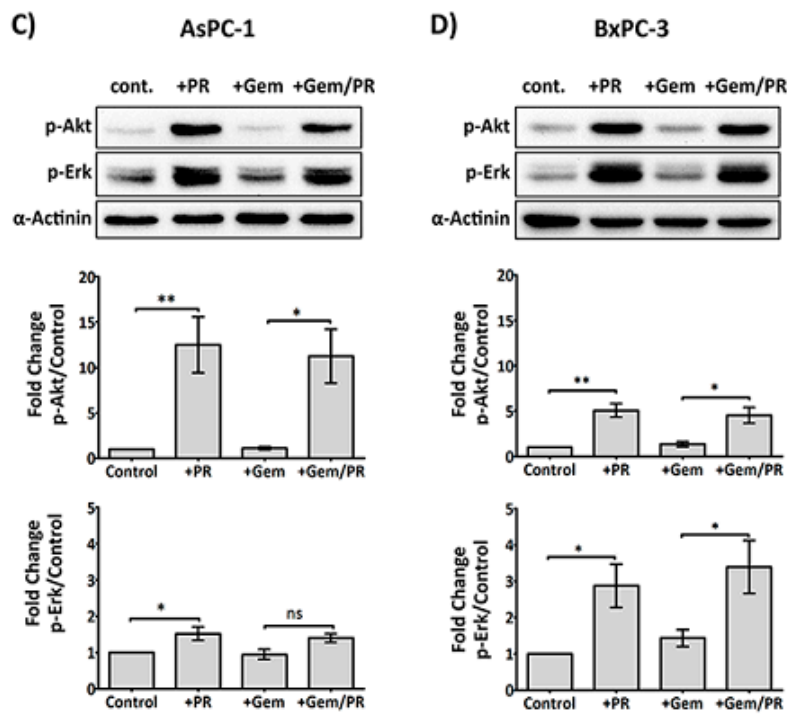

Figure 1. Platelet releasate (PR) promotes pancreatic ductal adenocarcinoma (PDAC) cell survival in the presence of gemcitabine. PDAC cell lines, AsPC-1 (A) or BxPC-3 (B), were seeded at 5000 cells/well, in a 96-well plate for $24 \mathrm{~h}$, then treated with platelet releasate (PR) \pm gemcitabine (0 to $100 \mu \mathrm{M})$ for $72 \mathrm{~h}$. PR was prepared from xl-CRP $(1 \mu \mathrm{g} / \mathrm{mL})$-aggregated platelets $\left(5 \times 10^{9}\right.$ platelets $\left./ \mathrm{mL}\right)$ and used in cell culture at 1:10 dilution, resulting in the final concentration equivalent to the amount of releasate from $5 \times 10^{8}$ platelets $/ \mathrm{mL}$. Cell proliferation was quantified by Alamar blue reagent, a non-toxic cell health indicator dye that is converted to fluorescent red colour in living cells. The fluorescence intensity (ex/em $570 \mathrm{~nm} / 610 \mathrm{~nm}$ ) was quantified by a multi-mode plate reader (PerkinElmer). Statistics were calculated using two-way ANOVA, with $n=5$ for (A) and $n=4$ for $(\mathbf{B}),{ }^{* * *} p<0.0001,{ }^{*} p<0.05$. Changes in the phosphorylation status of Protein kinase B (Akt) and Extracellular signal-regulated kinase (Erk) in cancer cells at $2 \mathrm{~h}$ were determined following high-dose gemcitabine treatment $(25 \mu \mathrm{M}$ for AsPC-1 and $10 \mu \mathrm{M}$ for BxPC-3). Briefly, cancer cells were seeded at $3 \times 10^{5}$ cells/well in a 6 -well plate for $24 \mathrm{~h}$, serum starved for $6 \mathrm{~h}$, then treated with $\mathrm{PR} \pm$ gemcitabine for $2 \mathrm{~h}$. Cell lysates were separated by SDS-PAGE and immunoblotted using phospho-specific antibodies for Akt (upper panel) and Erk1/2 (middle panel). Alpha $(\alpha)$-actinin (lower panel) was used as loading controls for each protein. The expression level of the protein of interest was quantified and normalised to the loading control with automated software Image Lab (version 5.1, BioRad, CA, USA) and GraphPad Prism 5 (GraphPad Software, Inc, CA, USA). The columns represent fold changes in protein expression level compared to vehicle control-treated cells. Data are presented as mean \pm SEM. One-way ANOVA with post-hoc Bonferroni's Multiple Comparison Test was used to examine the significance of the mean, with $n \geq 4$ for (C) and $n \geq 3$ for (D), ${ }^{* *} p<0.001,{ }^{*} p<0.05$. Abbreviations: Gem-gemcitabine, xl-CRP-cross-linked Collagen-related peptide, PDAC - pancreatic ductal adenocarcinoma, PR-platelet releasate, Akt-Protein kinase B, Erk—Extracellular signal-regulated kinase, SDS-PAGE—sodium dodecyl sulfate polyacrylamide gel electrophoresis, ANOVA-Analysis of variance. 
2.2. Platelet Releasate Induces A Rapid Upregulation of the EMT Transcription Factor, Slug, Independent of the TGF $/$ Smad Pathway

Platelets can affect a change in cancer cells by upregulation of relevant transcription factors involved in the EMT process, including Snail, Slug, and Twist $[10,27,28]$. One such marker, Slug, has recently been implicated in supporting chemotherapy resistance activity in tumour cells $[13,14,29]$. The main platelet-derived soluble factor that has been suggested to regulate Slug expression is TGF $\beta 1$, through the Smad effector pathway [10,30]. However, TGF $\beta /$ Smad signalling defects and non-Smad signalling pathways have been observed in several conditions and cell types [31-33]. Therefore, we investigated the expression of Slug and TGF $\beta$ /Smad signalling in AsPC-1 and BxPC-3 cells stimulated with platelet releasate.

The releasate used in our study was determined to contain approximately $10 \mathrm{ng} / \mathrm{mL}$ of TGF- $\beta 1$ by ELISA (Supplementary Figure S1), which is in line with the previous reported literature [34]. As shown in Figure 2A,B, platelet releasate induced a rapid upregulation of Slug expression after $2 \mathrm{~h}$ in both AsPC-1 and BxPC-3. Interestingly, the increase in Slug by platelet releasate was not entirely due to TGF $\beta 1$, as Slug level remained upregulated in the presence of a TGF $\beta 1$ receptor inhibitor (SB431542 (Tocris Bioscience, Bristol, UK), Figure 2C,D. And the increase of Slug expression by TGF $\beta 1$ is much more elevated in BxPC-3 compared to AsPC-1, suggesting the cell lines may have distinct responses to TGF $\beta 1$ (Supplementary Figure S2). Additionally, SB431542 reduced the phosphorylation of Smad2/3 in both platelet releasate-stimulated AsPC-1 and BxPC-3 cells. Moreover, platelet releasate was able to sustain Slug upregulation in cancer cells challenged with gemcitabine (Figure 2E,F). 
A)

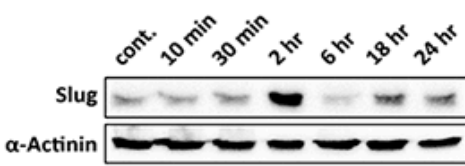

C)

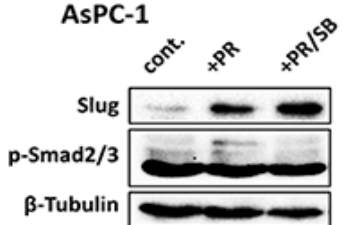

E)

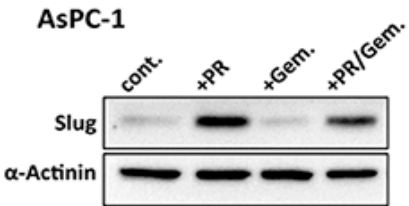

F)

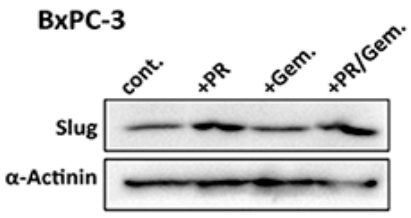

B)

BxPC-3 + Platelet Releasate

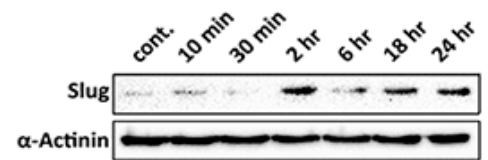

D)
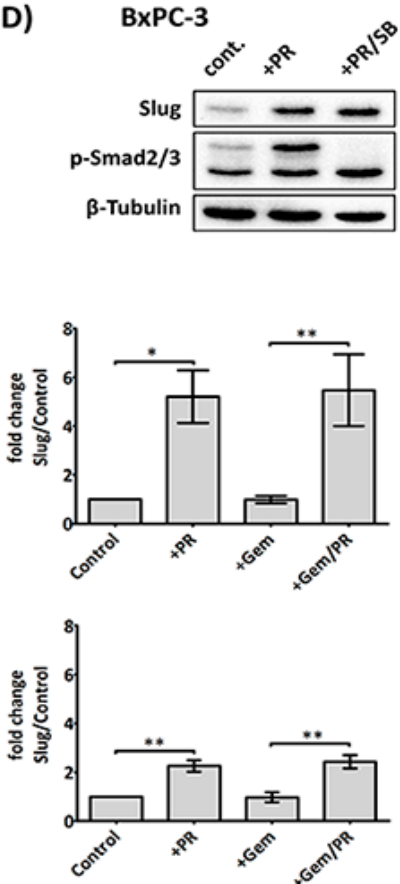

Figure 2. PR induces a rapid upregulation of Slug, an EMT and chemotherapy resistance marker, independent of the TGF $\beta 1 /$ Smad pathway. Representative immunoblots (A) and (B) show Slug expression in AsPC-1 and BxPC-3 cells after time course treatment with platelet releasate (PR). $2 \times 10^{5}$ cancer cells per well were seeded in a 12-well plate for $24 \mathrm{~h}$, serum starved for $6 \mathrm{~h}$, then PR was added to the culture media (final concentration of PR was equivalent to releasate from $5 \times 10^{8}$ platelets $/ \mathrm{mL}$ ) for $10 \mathrm{~min}, 30 \mathrm{~min}, 2 \mathrm{~h}, 6 \mathrm{~h}, 18 \mathrm{~h}$ and $24 \mathrm{~h}$. Representative immune blots (C) and (D) show Slug and pSmad2/3 expression in AsPC- 1 and BxPC-3 cells after treatment with PR $\pm 10 \mu \mathrm{M}$ SB431542 (TGF 31 receptor inhibitor) or 0.1\%DMSO (vehicle control, Sigma-Aldrich, St. Louis, MO, USA) for $2 \mathrm{~h}$. Cell lysates were separated by SDS-PAGE and immunoblotted using specific antibodies for Slug (upper panel), p-Smad2/3 (middle panel) and loading control protein $\alpha$-actinin or $\beta$-tubulin (lower panel). Each of the immunoblots (A)-(D) is representative of two independent experiments with similar results. Representative immune blots (E) and (F) and the associated bar graphs show Slug expression in AsPC-1 and BxPC-3 cells after $2 \mathrm{~h} \mathrm{PR} \pm$ gemcitabine treatment. The expression level of the protein of interest was quantified relative to the loading control. The graph columns represent fold changes in protein expression level compared to vehicle-treated cells $(n=4$ for $(\mathbf{E})$ and $n>3$ for $(\mathbf{F}))$. One way ANOVA with post.-hoc Bonferroni's Multiple Comparison Test was used to examine the significance of the mean $(* * p<0.001, * p<0.05)$.

\subsection{Platelets Modulate hENT1 and CDD in PDAC Cells}

As platelet releasate could promote cancer cell proliferation and activation of key kinases involved in supporting cell survival, Erk and Akt, despite the presence of gemcitabine, we hypothesised that platelet-derived factors could modulate the cellular metabolism and uptake of gemcitabine to counteract its cytotoxic effects. The influx of gemcitabine depends primarily on the nucleoside transporters [35]. Once inside the cell, gemcitabine can be deactivated by CDD, an enzyme whose increased expression has been implicated in chemoresistance [36,37]. As shown in Figure 3, platelet 
releasate (equivalent to $1 \times 10^{8}$ platelets $/ \mathrm{mL}$ ) significantly augmented the expression of CDD in both AsPC-1 and BxPC-3 cell lines. The level of hENT1 was decreased by platelet releasate in the two cell lines, with statistically significant reduction observed in AsPC-1. Unstimulated or degranulated platelets, however, were less effective at modulating the expression levels of hENT1 and CDD.

A)

AsPC-1

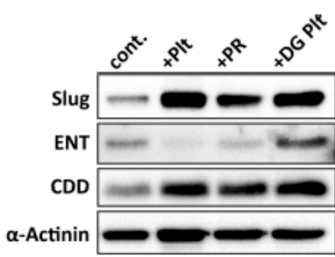

C)
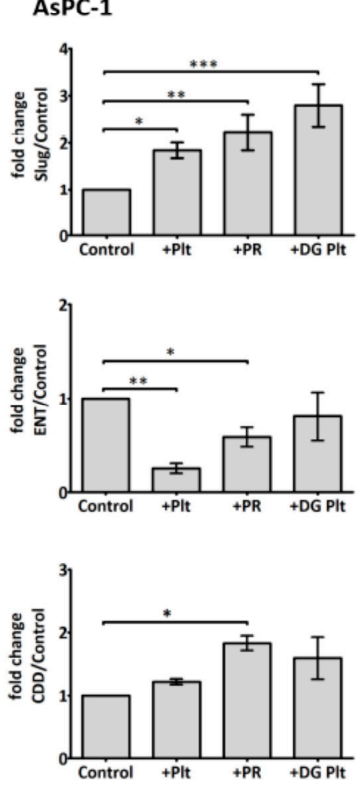

B)

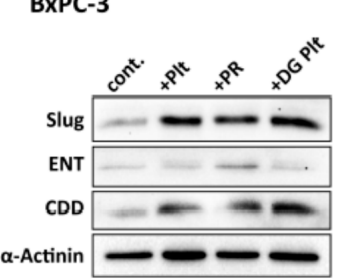

D)
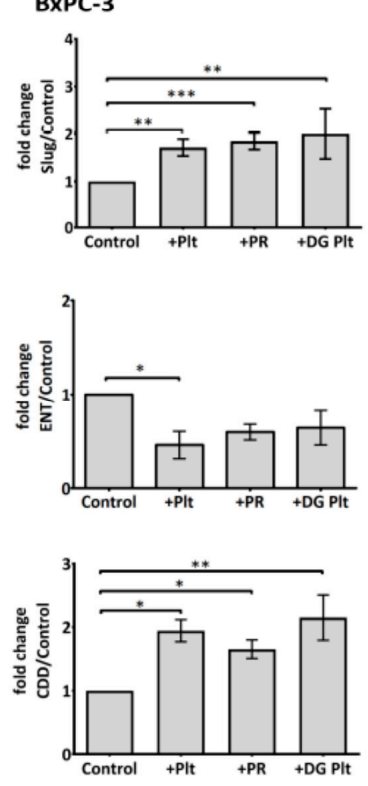

Figure 3. Platelets modulate the expression of Slug, human equilibrative nucleoside transporter 1 (hENT1) and cytidine deaminase (CDD) in PDAC cells. Representative immunoblots (A) and (B) show the expression of Slug, hENT1 and CDD in AsPC-1 and BxPC-3 after treatment with platelets (Plt), platelet releasate (PR) or degranulated platelets (DG Plt) for $24 \mathrm{~h}$. PR and degranulated platelets (DG Plt) were isolated from activated platelets. Briefly, platelets $\left(1 \times 10^{9} / \mathrm{mL}\right)$ were aggregated by incubating with $1 \mu \mathrm{g} / \mathrm{mL}$ CRP for $30 \mathrm{~min}$ then the supernatant (i.e., PR) and the pellet (i.e., DG Plt) were separated by centrifugation ( $5000 \mathrm{~g}$ for $10 \mathrm{~min}$ ). The pellet was resuspended in Tyrode's buffer, using the initial volume. The cancer cells were seeded in a 6-well plate at $3 \times 10^{5}$ per well for $24 \mathrm{~h}$, then incubated with Plt, PR or DG Plt to the final concentration equivalent to $1 \times 10^{8}$ platelets $/ \mathrm{mL}$ for $24 \mathrm{~h}$ in serum-free media. Cell lysates were separated by SDS-PAGE and immunoblotted using specific antibodies for Slug, hENT1, CDD and loading control protein $\alpha$-actinin. Bar graphs (C) and (D) show the changes in the expression of Slug, hENT1 and CDD in AsPC-1 and BxPC-3 after different treatments. The expression level of the protein of interest was quantified relative to the loading control and normalised to the negative control group $(n \geq 3)$. Data are presented as mean \pm SEM. One way ANOVA with post-hoc Bonferroni's Multiple Comparison Test was used to examine the significance of the mean. ${ }^{* * *} p<0.0001,{ }^{* *} p<0.001,{ }^{*} p<0.05$.

\subsection{Slug Modulates Expression of CDD and hENT1 in PDAC Cells}

As platelet releasate was demonstrated to significantly increase Slug and alter the levels of CDD and hENT1 in PDAC cells, we next examined whether Slug is necessary for the modulation of CDD 
and hENT1 expression. A SLUG messenger RNA (mRNA) knockdown assay, using two different short interfering RNA (siRNA) sequences specific for SLUG mRNA and an irrelevant siRNA negative control, was performed to assess the changes in the expression of CDD and hENT1 in PDAC cells. Figure 3 clearly shows that the expression of CDD was significantly suppressed and, conversely, hENT1 was significantly increased in the absence of Slug in AsPC-1 cells. The protein expression change trends were also observed in the BxPC-3 cells, but the modulation was less pronounced and not statistically significant.

\section{A) AsPC-1}

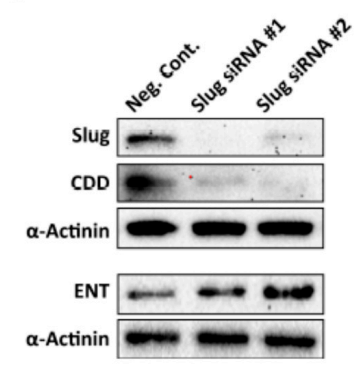

C) AsPC-1
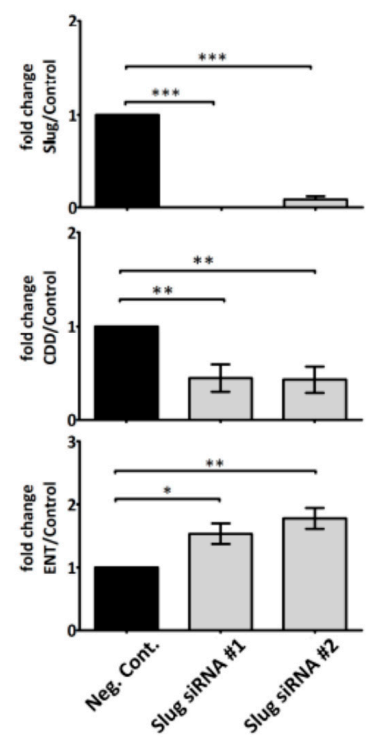

B) $\mathrm{BxPC}-3$

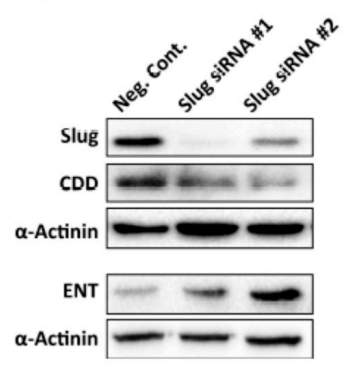

D) BxPC-3
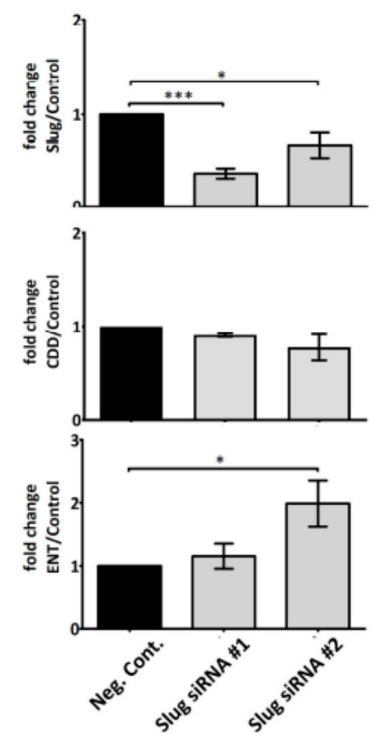

Figure 3. Slug mediates the expression level of CDD and hENT1 in PDAC. Representative immunoblots (A) and (B) show the expression of Slug, hENT1 and CDD in AsPC-1 and BxPC-3 after Slug-specific siRNA treatment. $3 \times 10^{5}$ cancer cells were seeded in 6-well plate for $24 \mathrm{~h}$. Slug siRNAs (the number $\# 1$ and \#2 designate two different Slug siRNA sequences) or a negative control siRNA (75 nM) in serum/antibiotic-free media were added to the adherent cells and incubated for $24 \mathrm{~h}$. The media was then replaced with fresh media ( $+10 \%$ fetal bovine serum (FBS)) and cells incubated for a further $24 \mathrm{~h}$ before cells were lysed and examined for the expression of the proteins of interest. Bar graphs (C) and (D) show the expression of Slug, hENT1, CDD and loading control $\alpha$-actinin in AsPC- 1 and BxPC-3 post siRNA treatment. The expression levels were quantified relative to the loading control. The columns represent the fold change of protein levels relative to the negative control siRNA treated cells $(n \geq 3)$. Data are presented as mean \pm SEM. One way ANOVA with post-hoc Bonferroni's Multiple Comparison Test was used to examine the significance of the mean ${ }^{* * *} p<0.0001,{ }^{* *} p<0.001,{ }^{*} p<0.05$. Neg. Cont.: negative control. 


\subsection{Platelet-Derived ADP and ATP Promote Slug and CDD Expression Levels in PDAC Cells}

Several purinergic receptors are reported to be expressed on cancer cells, including PDAC cells, ((e.g., $\mathrm{P}_{2} \mathrm{Y}_{1}$ and $\mathrm{P} 2 \mathrm{X}_{7}$, which are adenosine diphosphate (ADP) and adenosine triphosphate (ATP) receptor, respectively)) [38,39]. More interestingly, recent studies suggest that purinergic signalling can promote invasiveness and EMT in prostate cancer cells [40,41]. Since ADP and ATP are secreted from activated platelets, and our above data indicated that platelet-derived soluble factors were responsible for modulating Slug and CDD expression, we next investigated whether the enzyme apyrase-which catalyses the hydrolysis of ATP and ADP-could ameliorate the effect of platelet releasate on Slug and CDD expression in PDAC cells. Our results show that apyrase $(1 \mathrm{U} / \mathrm{mL})$ significantly negated PR-induced upregulation of Slug and CDD in cancer cells (Figure 4A,B) but apyrase did not significantly modulate hENT1 expression level (Supplementary Figure S3). Exogenous ADP and ATP $(100 \mu \mathrm{M})$ also increased the expression levels of Slug and CDD in PDAC cells (Figure 4C,D).
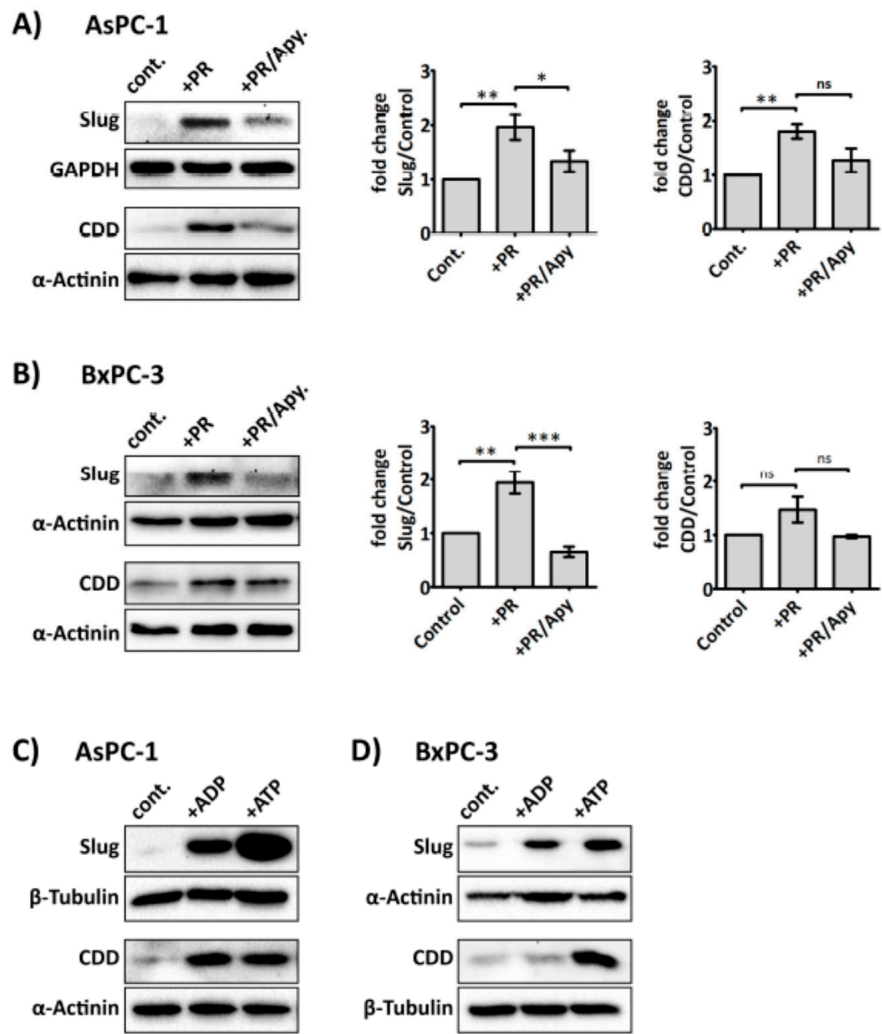

D) BxPC-3

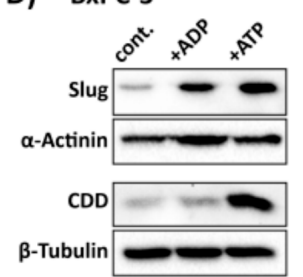

Figure 4. Platelet-derived ADP and ATP mediate Slug and CDD expression in PDAC cells. Representative immunoblots and bar graphs (A) and (B) show Slug and CDD expression in AsPC-1 and BxPC-3 cells after incubation with PR or PR pre-treated with apyrase $(1 \mathrm{U} / \mathrm{mL}$, for $30 \mathrm{~min}$ at $37^{\circ} \mathrm{C}$ ). $3 \times 10^{5}$ cells were seeded in a 6 -well plate for $24 \mathrm{~h}$, then PR or apyrase pre-treated PR were added to the cancer cells for a further $24 \mathrm{~h}$ in serum-free media. The final concentration of PR used was equivalent to releasate from $5 \times 10^{8}$ platelets $/ \mathrm{mL}$. Cell lysates were prepared and used in SDS-PAGE and immunoblotting as previously described. The expression levels of the proteins of interest were quantified relative to the loading control. The columns represent fold-change in protein expression level compared to control, vehicle-treated cells. Data are presented as mean $\pm \mathrm{SEM}$. One way ANOVA with post-hoc Bonferroni's Multiple Comparison Test was used to examine the significance of the mean. $n \geq 4$. ${ }^{* * *} P<0.0001,{ }^{* *} P<0.001,{ }^{* *} P<0.05$. Representative immunoblots $(\mathbf{C})$ and (D), from two independent experiments, show Slug and CDD expression in AsPC-1 and BxPC-3 after exogenous ADP or ATP $(100 \mu \mathrm{M})$ treatment for 24 h. cont.: control. 
2.6. The Antiplatelet Drug, Ticagrelor, Reduces PR-Induced Akt, Erk Activation and Slug Upregulation in Cancer Cells

In view of the fact that platelet-derived ADP / ATP could significantly promote upregulation of Slug and CDD, two important markers of gemcitabine resistance, we, therefore, assessed whether AsPC-1 and BxPC-3 expressed the ADP receptor, $\mathrm{P}_{2} \mathrm{Y}_{12}$ by western blot analysis (Supplementary Figure S4), which confirmed its expression in both cell lines. We therefore assessed whether the clinically available $\mathrm{P}_{2} \mathrm{Y}_{12}$ receptor antagonist (ticagrelor) reduced PR-initiated signals in cancer cells. Cancer cells adherent in 6-well plates were treated with $\mathrm{PR} \pm$ ticagrelor $(10 \mu \mathrm{M})$ and incubated for $2 \mathrm{~h}$ in serum-free media. As shown in Figure 5, ticagrelor negated the PR effect on Akt, Erk activation and Slug upregulation in AsPC-1 and BxPC-3. Exogenous ADP and ATP $(100 \mu \mathrm{M})$ were also able to induce Akt, Erk activation and Slug upregulation in cancer cells and these effects were completely blocked by ticagrelor $(10 \mu \mathrm{M})$ (Supplementary Figure S5). 
A) AsPC-1

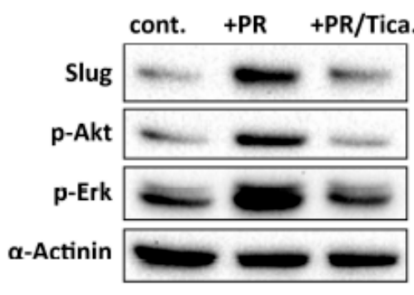

C) AsPC-1
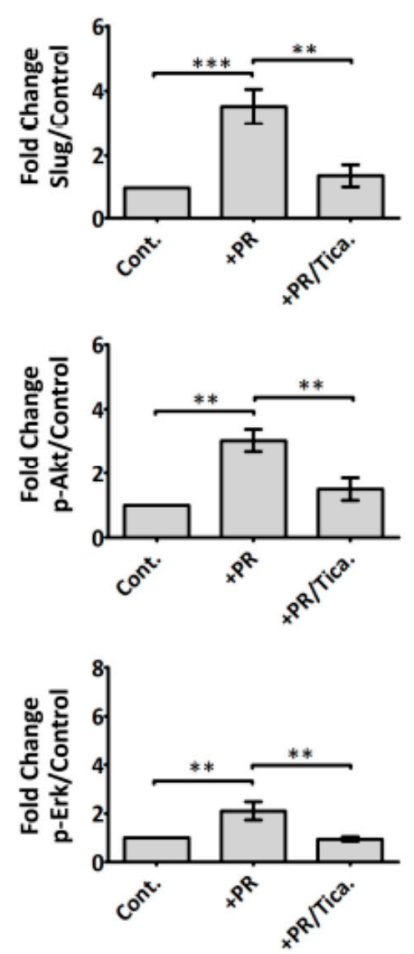

B) $\quad$ BxPC-3

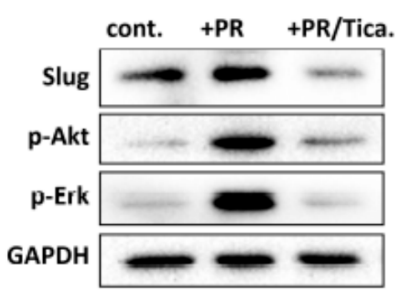

D) $\mathrm{BxPC}-3$
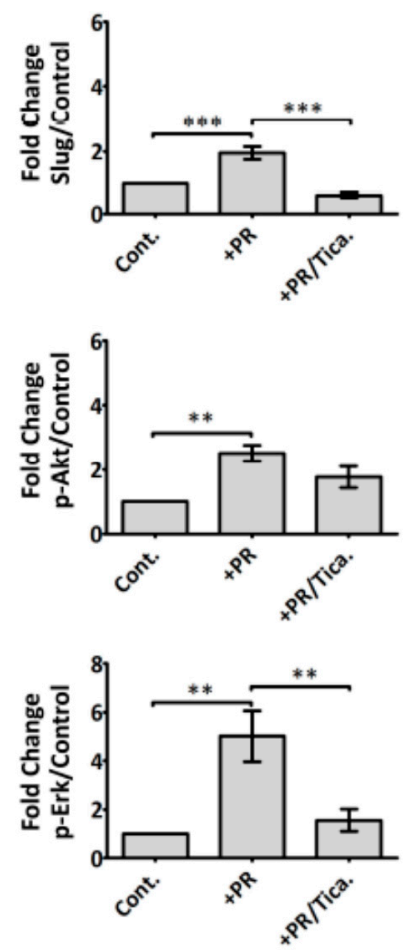

Figure 5. Anti-platelet drug ticagrelor, an antagonist of the purinergic receptor $\mathrm{P}_{2} \mathrm{Y}_{12}$ receptor, reduces the effects of PR on cancer cells. Representative immunoblots show Slug, p-Akt and p-Erk expression in AsPC-1 and BxPC-3 cells after incubation with PR \pm ticagrelor (Tica, $10 \mu \mathrm{M}$ ) for $2 \mathrm{~h}$. Sample preparations and immunoblotting were performed as previously described. The final concentration of PR used was equivalent to releasate from $5 \times 10^{8}$ platelets $/ \mathrm{mL}$. Bar graphs (C) and (D) show the expression levels of the proteins of interest relative to the loading control. Columns represent fold change in protein expression level compared to control non-treated cells. $n \geq 5$. ${ }^{* * *} p<0.0001$, ${ }^{* *} p<0.001,{ }^{* *} p<0.05$. Data are presented as mean \pm SEM. One way ANOVA with post-hoc Bonferroni's Multiple Comparison Test was used to examine the significance of the mean. cont.: control.

\section{Discussion}

Various types of cancer cells, including PDAC cells, can activate platelets, which in turn, can support tumour cell growth and metastasis [10,42-44]. Recent clinical studies have indicated an association between platelets and poor chemotherapeutic responses in cancer patients $[45,46]$. However, the mechanisms by which platelets confer chemoresistance to cancer cells have remained unclear. In accordance with several investigative studies on the impact of platelets on tumour growth $[9,47,48]$, our data showed that platelet-derived factors could promote proliferation of AsPC- 1 and BxPC-3 cancer cells and protected them from the cytotoxic effects of gemcitabine (Figure 1A,B). Previous 
studies indicated that cellular Akt or Erk activity was associated with gemcitabine resistance [49-52]. Here, after exposure to platelet releasate, a significant increase of Akt and Erk phosphorylation was detected in both cell lines, and the activation of these survival signalling molecules remained in the presence of gemcitabine (Figure 1C,D). Our results suggest that platelet releasate contained an active component (or components) capable of regulating Akt and Erk phosphorylation and promoting cell growth under chemotherapy.

Platelet-derived TGF- $\beta 1$ has been implicated as the major signalling regulator of cancer progression towards an invasive phase, through an induction of EMT $[10,53,54]$. Critical downstream effectors of TGF- $\beta 1$ include receptor-regulated Smad2/3 [55-57] and Slug [58,59], a transcriptional repressor and regulator of EMT and chemoresistance [29,60]. In our study, the expression of Slug in both PDAC cell lines was significantly, and rapidly, augmented by the addition of platelet releasate (Figure 2A,B). However, the level of Slug did not lessen in the presence SB431542, a TGF- $\beta 1$ receptor blocker. Furthermore, the phosphorylation of Smad2/3 by platelet releasate was inhibited by SB431542 in both cell lines, suggesting that the increase in Slug expression by PR in AsPC-1 and BxPC-3 was independent of TGF- $\beta 1 R$ signalling (Figure 2C,D). The exposure to exogenous TGF $\beta 1$ showed that the cells may have distinct responses to the cytokine, as the upregulation of Slug expression was much more elevated in BxPC-3. Therefore, our data suggest that inhibition of platelet-derived TGF- $\beta 1$ signalling was dispensable under these conditions and other factors apart from TGF- $\beta 1$ could promote Slug expression. More importantly, when the cancer cells were grown in the presence of platelet-derived soluble factors and challenged with gemcitabine, Slug expression stayed elevated (Figure 2E,F). The signalling cascade through the complex Smad2/3/4 may be very important in some type of pancreatic cancer cells as Smad4 is a critical mediator of TGF $\beta$ signalling. However, Smad 4 is also known to be inactivated in more than $50 \%$ of PDAC patients, and several in vitro studies have indicated that both AsPC1 and BxPC3 lack Smad4 protein expression [61-65], therefore its contribution to signal transduction is negligible in regards to these particular cancer cell lines.

The effectiveness of gemcitabine relies on the function of several proteins, including the influx protein, ENT1 [35], deoxycytidine kinase (dCK) (phosphorylates gemcitabine into an active form) [66], and CDD (deactivates gemcitabine) [36,37]. In our hands, we observed a statistically significant upregulation of CDD expression in cancer cells cultured with platelet releasate (Figure 3), suggesting that soluble factors from platelets could increase the capacity of cancer cells to deactivate gemcitabine. Inversely, the expression of hENT1 was decreased, at a statistically significant level in AsPC-1 and a trend reduction in BxPC-3. Reduced hENT1 implies that a lesser amount of gemcitabine could be transported inside the cells, thus increasing cell survival. Interestingly, degranulated platelets were also capable of instigating a significant upregulation of Slug in the cancer cells, suggesting a physical interaction between the surface molecules of platelets and cancer cells could induce intracellular signalling down the EMT pathway. Similarly, Labelle et al. have previously observed that a direct contact between cancer cells and platelets can activate a nuclear factor kappa-light-chain-enhancer of activated B cells, Nf-kB, pathway and EMT-like transformation in cancer cells independent of platelet-released factors [10]. Although studies indicate a common pathway for Nf-kB and Slug in regulating EMT [67,68], currently it is still unclear which receptors are involved in this cascade, and more studies are required to understand this interaction better.

The results of Slug knockdown indicated that the expression levels of CDD and hENT1 were dependent on Slug (Figure 3). Absent or reduction of Slug, especially in AsPC-1 cells, significantly reduced CDD and increased hENT1 expression, respectively. BxPC-3 Slug knockdown showed similar trends but were not statistically significant. This may be due in part to BxPC-3 being relatively more resistant to siRNA transfection. Our data highlight the novel role of Slug in the gemcitabine metabolism pathway and further validate its role in acquired-chemoresistance.

Since the increase of Slug expression by platelet releasate was not significantly dependent of platelet-derived TGF- $\beta 1$, we hypothesised that Slug expression could be regulated by platelet-derived nucleotides, ADP and ATP. Platelets release ADP and ATP from their dense granules after interacting 
with stimuli such as cancer cells. Several studies have suggested nucleotides to be important in promoting tumour metastasis by increasing the permeability of the transendothelial barrier [43], maintaining tumour cell survival under duress [69,70], and eliciting EMT-related genes in cancer cells [40]. Here, we show that degradation of ATP and ADP by apyrase prevented the platelet releasate-induced increase of Slug and CDD expression in PDAC cells (Figure 4A,B). Furthermore, exogenously supplied ADP and ATP to AsPC-1 and BxPC-3 increased both the Slug and CDD expression level, suggesting a regulatory role for ADP and ATP in EMT and gemcitabine metabolism in cancer cells.

Activation of purinergic receptors, including P2Y $\mathrm{Y}_{1}[71]$ and $\mathrm{P} 2 \mathrm{X}_{7}[39,72]$, in PDAC cells have been shown to promote cancer cell growth. Here, we report a low-level expression of the ADP receptor P2Y 12 in PDAC cell lines AsPC-1 and BxPC-3 (Supplementary Figure S4). This corroborated with the Human Protein Atlas data (https:/ / www.proteinatlas.org/ENSG00000169313-P2RY12/pathology) which indicated elevated $\mathrm{P}_{2} \mathrm{Y}_{12}$ expression in pancreatic cancer tissue and negligible detection level in normal tissue [73,74]. P2 $\mathrm{Y}_{12}$, considered the predominant receptor that mediates ADP-induced platelet activation [75] and detected primarily in platelets and brain tissues [76,77] has also been detected in other cell types including smooth muscle cells $[78,79]$ and pancreatic islets [80]. Here, our data show that ticagrelor, an ADP receptor $\mathrm{P} \mathrm{Y}_{12}$ antagonist and clinically available antiplatelet drug, was effective at reducing platelet releasate-induced cancer cell activation (Figure 5). This was a direct effect of ticagrelor on the cancer cells as the cells were exposed only to platelet-derived soluble factors, not whole platelets. As ATP is an unstable molecule and can be rapidly hydrolysed to ADP and phosphate, the effects observed with exogenously administered ATP on the cancer cells may also be the results of the action of ADP. This is corroborated by the inhibitory effect of ticagrelor on cancer cells supplied with extracellular ATP (Supplementary Figure S5). It must be noted that the action of ticagrelor on the cell lines may also be due to its ability to weakly inhibit the uptake of adenosine by hENT1 [81,82], therefore preventing the pro-survival effect provided by adenosine uptake [83]. Furthermore, a drug review information (NDA number 22-433) from the U.S. Food and Drug Administration indicated that ticagrelor, at lower $\mu \mathrm{M}$ concentrations, can inhibit adenosine A3 receptor, and phosphodiesterase 5 (PDE5) [84]. Studies have shown that a blockage of A3 receptor reduced viability and chemotherapy resistance in glioblastoma stem-like cancer cells [85], whereas, inhibition of PDE5 potentiated gemcitabine in pancreatic cancer cells [86].

In summary, we show here for the first time that factors released from activated platelets can support PDAC cells to better survive under gemcitabine challenge by modulating CDD and hENT1 expression, both of which are controlled by Slug. The chemoresistance was mediated largely through platelet-derived nucleotides ADP and ATP. As tumours are exposed to high levels of extracellular nucleotides and nucleosides within the microenvironment [87-89], a supplementary strategy to target platelet activation and purinergic signalling in cancer treatment may be beneficial. Additionally, we showed a direct anti-cancer effect of ticagrelor, warranting a further assessment of the drug in the context of cancer therapy.

\section{Materials and Methods}

\subsection{Reagents and Cell Lines}

Apyrase, ADP, ATP, gemcitabine and ticagrelor were obtained from Sigma-Aldrich, (St. Louis, $\mathrm{MO}, \mathrm{USA}$ ). Inhibitor of the transforming growth factor- $\beta$ (TGF- $\beta$ ) type I receptor, SB431542 was from Tocris Bioscience, Bristol, UK. AsPC-1 and BxPC-3 cell lines were obtained from ATCC and tested negative for mycoplasma (tissue culture facility routine testing). Cells were maintained in RPMI 1640 medium supplemented with $2 \mathrm{mM}$ glutamine, $1 \mathrm{mM}$ Sodium Pyruvate, $1 \mathrm{mM}$ non-essential amino acids (all from Gibco ${ }^{\circledR}$ Life Technologies Australia Pty Ltd., Mulgrave, Australia), and 10\% Foetal Bovine Serum (FBS, from Bovogen Biologicals, Keilor East, Australia). 


\subsection{Preparation of Human Washed Platelets}

Blood from healthy volunteers was drawn into ACD (acid-citrate-dextrose-15\% v/v) with informed consent in concordance with the Curtin University Human Research Ethics Committee (approval number HR54/2014). Washed platelets were prepared as previously described [90]. Platelet count was adjusted to $5 \times 10^{9} / \mathrm{mL}$ and suspended in HEPES-Tyrode's buffer ( 5 mM HEPES, $5.5 \mathrm{mM}$ glucose, $138 \mathrm{mM} \mathrm{NaCl}, 12 \mathrm{mM} \mathrm{NaHCO} 3,0.49 \mathrm{mM} \mathrm{MgCl}_{2}, 2.6 \mathrm{mM} \mathrm{KCL}, 0.36 \mathrm{mM} \mathrm{NaH}_{2} \mathrm{PO}_{4}$, $1.8 \mathrm{mM} \mathrm{CaCl}_{2}, \mathrm{pH} 7.4$ ). To prepare degranulated platelets (DG Plt) and platelet releasate (PR), washed platelets were activated with cross-linked CRP (collagen-related peptide- $1 \mu \mathrm{g} / \mathrm{mL}$, Auspep, Tullamarine, Australia) at $37^{\circ} \mathrm{C}$ for $30 \mathrm{~min}$. The DG Plt pellet was separated from the PR supernatant by centrifugation at $5000 \mathrm{~g}$ for $10 \mathrm{~min}$.

\subsection{Cell Viability}

Cancer cells were seeded at 5000 cells/well in a 96-well plate. After $24 \mathrm{~h}$, the medium was replaced with serum-free RPMI 1640 medium supplemented with platelet releasate and gemcitabine $(0.1$ to $100 \mu \mathrm{M})$ and incubated for a further $72 \mathrm{~h}$. Cell viability was measured by detecting the metabolic activity of live cells using Alamar blue (Resazurin sodium salt, Sigma-Aldrich, St. Louis, MO, USA) as previously described [91]. Briefly, $10 \times$ Alamar blue was added as $10 \%$ of the sample volume; then the plate was incubated for $1 \mathrm{~h}$ (AsPC-1) or $2 \mathrm{~h}(\mathrm{BxPC}-3)$ at $37^{\circ} \mathrm{C}$. Alamar blue reagent is a non-toxic cell health indicator that is converted to fluorescent red colour in living cells, and the fluorescence (ex/em $570 \mathrm{~nm} / 610 \mathrm{~nm}$ ) was quantified by a plate reader (EnSpire Multimode, PerkinElmer ${ }^{\circledR}$, Waltham, MA, USA).

\subsection{Western Blot:}

The level of protein expression was examined by Western blot. Specific antibodies against Slug, p-Akt (Ser473), p-Smad2 (Ser465/467)/Smad3 (Ser423/425), p-Erk1/2(Thr202/Tyr204), $\beta$-tubulin, $\alpha$-Actinin and Glyceraldehyde 3-phosphate dehydrogenase (GADPH) were obtained from Cell Signaling Technology ${ }^{\circledR}$ (Danvers, MA, USA). Rabbit anti-CDD and hENT1 antibodies were obtained from Santa Cruz Biotechnology (Dallas, TX, USA). Rabbit $\mathrm{P}_{2} \mathrm{Y}_{12}$ [EPR18611] monoclonal antibody was obtained from Abcam Biotechnology (Cambridge, UK). Tumour cells were seeded in a 6-well plate. After $24 \mathrm{~h}$, cells were serum starved for $6 \mathrm{~h}$, then subjected to different treatments, and the plate was incubated for the specified time. Cells were then washed 3 times with ice-cold Tris Buffered Saline (TBS, $137 \mathrm{mM}$, sodium chloride, $20 \mathrm{mM}$ Tris, pH 7.6) and lysed in ice-cold cell extraction RIPA buffer (ThermoFisher Scientific Inc., Waltham, MA, USA) supplemented with Protease/Phosphatase Inhibitor Cocktail (Cell Signaling Technology ${ }^{\circledR}$, Danvers, MA, USA). Forty-five $\mu$ g of cell lysate was then analyzed by sodium dodecyl sulphate-polyacrylamide gel electrophoresis and immunoblotted for the relevant protein. Equal loading was verified by immunoblotting for the house-keeping proteins ( $\beta$-tubulin, $\alpha$-actinin or GADPH).

\subsection{Slug Knockdown}

Cancer cells were seeded at $3 \times 10^{5}$ cells/well in a 6-well plate and maintained for $24 \mathrm{~h}$. Slug siRNAs (two different Slug-specific siRNA sequences) or a negative control siRNA ( $75 \mathrm{nM}$ ), prepared using DharmaFECT1 transfection agent (GE Dharmacon, Lafayette, CO, USA) in serum/antibiotic-free media, were added to the adherent cells and incubated for $24 \mathrm{~h}$. The two Slug-specific siRNAs GAAUGUCUCUCCUGCACAA (\#1) and UCUCUCCUCUUUCCGGAUA (\#2) were purchased from GE Dharmacon, Lafayette, CO, USA. The Silencer ${ }^{\circledR}$ negative control (sequence: proprietary, designed to have no significant similarity to human sequences, catalogue \#AM4635) was from Ambion ${ }^{\circledR}$, (ThermoFisher Scientific Inc., Waltham, MA, USA). The media (containing the transfection mixture) was then replaced with fresh media (RPMI $+10 \%$ FBS), and the plate was further incubated for $24 \mathrm{~h}$. After washing cells with TBS, the cells were then lysed with RIPA buffer, and western blots used to 
examine protein levels of expression. It must be noted that the BxPC-3 cell line was relatively difficult to transfect, likely due to the expression of extracellular DNA on the cell surface [91], and to achieve efficient transfer of siRNAs, the cells were treated with DNase $(60 \mathrm{U} / \mathrm{mL}$, STEMCELL Technologies, Vancouver, BC, Canada) for $3 \mathrm{~h}$, then washed 3 times with EDTA (50 mM), before addition of the transfection mixture as described above.

\subsection{Statistical Analysis}

Data were analysed using GraphPad PRISM 5.0 software (GraphPad Software, Inc, CA, USA). Results are expressed as the mean \pm standard error (SEM). One-way ANOVA with posthoc Bonferroni's Multiple Comparison Test was used to examine the significance of the mean. Differences were considered significant at $p$-value less than 0.05 .

\section{Conclusions}

Our results report for the first time that platelets can regulate the expression of markers of gemcitabine resistance in pancreatic cancer cells, hENT1 and CDD. Slug, a mesenchymal transcription factor and mediator of EMT processes, was shown to regulate the expression of both hENT1 and CDD. Furthermore, we showed that platelet-derived ADP and ATP could modulate the level of Slug and CDD, and activated survival signals in cancer cells. Finally, ticagrelor, a P2 $\mathrm{Y}_{12}$ inhibitor, could act directly on the cancer cells and abrogated the survival signals initiated in cancer cells by platelet-derived ADP and ATP. Future studies are required to examine whether targeting platelet activation and purinergic signalling in cancer cell could reduce chemotherapy resistance and cancer metastasis.

Supplementary Materials: The following are available online at http:/ / www.mdpi.com/2072-6694/9/10/142/ s1.

Acknowledgments: The authors acknowledge the infrastructure and staff support provided by CHIRI, School of Biomedical Sciences, Faculty of Health Sciences, Curtin University. The authors would also like to acknowledge the support of the Curtin University Health Sciences Faculty International Research Scholarship and the Avner Pancreatic Cancer Foundation, Keith \& Ann Vaughan Pancreatic Cancer Fund.

Author Contributions: O.E. and P.M. designed the experiments. O.E. performed experiments and wrote the manuscript first draft. O.E., M.F., N.M., M.C.B. and P.M. provided scientific analysis and interpretation of data. M.C.B. and P.M. edited the final draft and performed a critical revision of the article.

Conflicts of Interest: The authors report no conflict of interest.

\section{References}

1. Falasca, M.; Kim, M.; Casari, I. Pancreatic cancer: Current research and future directions. Biochim. Biophys. Acta 2016, 1865, 123-132. [CrossRef] [PubMed]

2. Delluc, A.; Rousseau, A.; Delluc, C.; Le Moigne, E.; Le Gal, G.; Mottier, D.; van Dreden, P.; Lacut, K. Venous thromboembolism in patients with pancreatic cancer: Implications of circulating tissue factor. Blood Coagul. Fibrinolysis 2011, 22, 295-300. [CrossRef] [PubMed]

3. Weiler, H. A platelet cloak for tumor cells. Blood 2005, 105, 5-6. [CrossRef]

4. Palumbo, J.S.; Talmage, K.E.; Massari, J.V.; La Jeunesse, C.M.; Flick, M.J; Kombrinck, K.W.; Jirouskova, M.; Degen, J.L. Platelets and fibrin (ogen) increase metastatic potential by impeding natural killer cell-mediated elimination of tumor cells. Blood 2005, 105, 178-185. [CrossRef] [PubMed]

5. Kopp, H.-G.; Placke, T.; Salih, H.R. Platelet-derived transforming growth factor- $\beta$ down-regulates NKG2D thereby inhibiting natural killer cell antitumor reactivity. Cancer Res. 2009, 69, 7775-7783. [CrossRef] [PubMed]

6. Geddings, J.E.; Hisada, Y.; Boulaftali, Y.; Getz, T.M.; Whelihan, M.; Fuentes, R.; Dee, R.; Cooley, B.C.; Key, N.S.; Wolberg, A.S.; et al. Tissue factor-positive tumor microvesicles activate platelets and enhance thrombosis in mice. J. Thromb. Haemost. 2016, 14, 153-166. [CrossRef] [PubMed]

7. Mitrugno, A.; Williams, D.; Kerrigan, S.W.; Moran, N. A novel and essential role for FC $\gamma$ RIIa in cancer cell-induced platelet activation. Blood 2014, 123, 249-260. [CrossRef] [PubMed] 
8. Battinelli, E.M.; Markens, B.A.; Italiano, J.E., Jr. Release of angiogenesis regulatory proteins from platelet alpha granules: Modulation of physiologic and pathologic angiogenesis. Blood 2011, 118, 1359-1369. [CrossRef] [PubMed]

9. Pucci, F.; Rickelt, S.; Newton, A.P.; Garris, C.; Nunes, E.; Evavold, C.; Pfirschke, C.; Engblom, C.; Mino-Kenudson, M.; Hynes, R.O.; et al. PF4 promotes platelet production and lung cancer growth. Cell Rep. 2016, 17, 1764-1772. [CrossRef] [PubMed]

10. Labelle, M.; Begum, S.; Hynes, R.O. Direct signaling between platelets and cancer cells induces an epithelial-mesenchymal-like transition and promotes metastasis. Cancer Cell 2011, 20, 576-590. [CrossRef] [PubMed]

11. Guillem-Llobat, P.; Dovizio, M.; Bruno, A.; Ricciotti, E.; Cufino, V.; Sacco, A.; Grande, R.; Alberti, S.; Arena, V.; Cirillo, M.; et al. Aspirin prevents colorectal cancer metastasis in mice by splitting the crosstalk between platelets and tumor cells. Oncotarget 2016, 7, 32462-32477. [CrossRef] [PubMed]

12. Sanchez-Tillo, E.; Liu, Y.; de Barrios, O.; Siles, L.; Fanlo, L.; Cuatrecasas, M.; Darling, D.S.; Dean, D.C.; Castells, A.; Postigo, A. EMT-activating transcription factors in cancer: Beyond EMT and tumor invasiveness. Cell. Mol. Life Sci. 2012, 69, 3429-3456. [CrossRef] [PubMed]

13. Haslehurst, A.M.; Koti, M.; Dharsee, M.; Nuin, P.; Evans, K.; Geraci, J.; Childs, T.; Chen, J.; Li, J.; Weberpals, J.; et al. EMT transcription factors snail and slug directly contribute to cisplatin resistance in ovarian cancer. BMC Cancer 2012, 12. [CrossRef] [PubMed]

14. Tsukasa, K.; Ding, Q.; Yoshimitsu, M.; Miyazaki, Y.; Matsubara, S.; Takao, S. Slug contributes to gemcitabine resistance through epithelial-mesenchymal transition in CD133(+) pancreatic cancer cells. Hum. Cell 2015, 28, 167-174. [CrossRef] [PubMed]

15. Arumugam, T.; Ramachandran, V.; Fournier, K.F.; Wang, H.; Marquis, L.; Abbruzzese, J.L.; Gallick, G.E.; Logsdon, C.D.; McConkey, D.J.; Choi, W. Epithelial to mesenchymal transition contributes to drug resistance in pancreatic cancer. Cancer Res. 2009, 69, 5820-5828. [CrossRef] [PubMed]

16. Zheng, X.; Carstens, J.L.; Kim, J.; Scheible, M.; Kaye, J.; Sugimoto, H.; Wu, C.C.; LeBleu, V.S.; Kalluri, R. Epithelial-to-mesenchymal transition is dispensable for metastasis but induces chemoresistance in pancreatic cancer. Nature 2015, 527, 525-530. [CrossRef] [PubMed]

17. Plunkett, W.; Huang, P.; Xu, Y.Z.; Heinemann, V.; Grunewald, R.; Gandhi, V. Gemcitabine: Metabolism, mechanisms of action, and self-potentiation. Semin. Oncol. 1995, 22, 3-10. [PubMed]

18. Huang, P.; Plunkett, W. Induction of apoptosis by gemcitabine. Semin. Oncol. 1995, 22, 19-25. [PubMed]

19. Mini, E.; Nobili, S.; Caciagli, B.; Landini, I.; Mazzei, T. Cellular pharmacology of gemcitabine. Ann. Oncol. 2006, 17 (Suppl. 5), v7-v12. [CrossRef] [PubMed]

20. Perez-Torras, S.; Garcia-Manteiga, J.; Mercade, E.; Casado, F.J.; Carbo, N.; Pastor-Anglada, M.; Mazo, A. Adenoviral-mediated overexpression of human equilibrative nucleoside transporter 1 (hENT1) enhances gemcitabine response in human pancreatic cancer. Biochem. Pharmacol. 2008, 76, 322-329. [CrossRef] [PubMed]

21. Frese, K.K.; Neesse, A.; Cook, N.; Bapiro, T.E.; Lolkema, M.P.; Jodrell, D.I.; Tuveson, D.A. nab-Paclitaxel Potentiates Gemcitabine Activity by Reducing Cytidine Deaminase Levels in a Mouse Model of Pancreatic Cancer. Cancer Discov. 2012, 2, 260-269. [CrossRef] [PubMed]

22. Ebrahem, Q.; Mahfouz, R.; Ng, K.P.; Saunthararajah, Y. High cytidine deaminase expression in the liver provides sanctuary for cancer cells from decitabine treatment effects. Oncotarget 2012, 3, 1137-1145. [CrossRef] [PubMed]

23. Kizer, N.T.; Hatem, H.; Nugent, E.K.; Zhou, G.F.; Moore, K.; Heller, P.; Mutch, D.G.; Thaker, P.H. Chemotherapy response rates among patients with endometrial cancer who have elevated serum platelets. Int. J. Gynecol. Cancer 2015, 25, 1015-1022. [CrossRef] [PubMed]

24. Ho-Tin-Noé, B.; Goerge, T.; Cifuni, S.M.; Duerschmied, D.; Wagner, D.D. Platelet granule secretion continuously prevents intratumor hemorrhage. Cancer Res. 2008, 68, 6851-6858. [CrossRef] [PubMed]

25. Golebiewska, E.M.; Poole, A.W. Platelet secretion: From haemostasis to wound healing and beyond. Blood Rev. 2015, 29, 153-162. [CrossRef] [PubMed]

26. Erpenbeck, L.; Schon, M.P. Deadly allies: The fatal interplay between platelets and metastasizing cancer cells. Blood 2010, 115, 3427-3436. [CrossRef] [PubMed] 
27. Dovizio, M.; Maier, T.J.; Alberti, S.; Di Francesco, L.; Marcantoni, E.; Münch, G.; John, C.M.; Suess, B.; Sgambato, A.; Steinhilber, D.; et al. Pharmacological inhibition of platelet-tumor cell cross-talk prevents platelet-induced overexpression of cyclooxygenase-2 in HT29 human colon carcinoma cells. Mol. Pharmacol. 2013, 84, 25-40. [CrossRef] [PubMed]

28. Jia, Y.T.; Zhang, S.Q.; Miao, L.L.; Wang, J.B.; Jin, Z.J.; Gu, B.; Duan, Z.H.; Zhao, Z.L.; Ma, S.M.; Zhang, W.J.; et al. Activation of platelet protease-activated receptor- 1 induces epithelial-mesenchymal transition and chemotaxis of colon cancer cell line SW620. Oncol. Rep. 2015, 33, 2681-2688. [CrossRef] [PubMed]

29. Kurrey, N.K.; Jalgaonkar, S.P.; Joglekar, A.V.; Ghanate, A.D.; Chaskar, P.D.; Doiphode, R.Y.; Bapat, S.A. Snail and slug mediate radioresistance and chemoresistance by antagonizing p53-mediated apoptosis and acquiring a stem-like phenotype in ovarian cancer cells. Stem Cells 2009, 27, 2059-2068. [CrossRef] [PubMed]

30. Derynck, R.; Akhurst, R.J.; Balmain, A. TGF- $\beta$ signaling in tumor suppression and cancer progression. Nat. Genet. 2001, 29, 117-129. [CrossRef] [PubMed]

31. Kretzschmar, M. Transforming growth factor- $\beta$ and breast cancer: Transforming growth factor- $\beta /$ SMAD signaling defects and cancer. Breast Cancer Res. 2000, 2, 107. [CrossRef] [PubMed]

32. Kretschmer, A.; Moepert, K.; Dames, S.; Sternberger, M.; Kaufmann, J.; Klippel, A. Differential regulation of TGF- $\beta$ signaling through Smad2, Smad3 and Smad4. Oncogene 2003, 22, 6748-6763. [CrossRef] [PubMed]

33. Hong, M.; Wilkes, M.C.; Penheiter, S.G.; Gupta, S.K.; Edens, M.; Leof, E.B. Non-Smad transforming growth factor- $\beta$ signaling regulated by focal adhesion kinase binding the p85 subunit of phosphatidylinositol 3-kinase. J. Biol. Chem. 2011, 286, 17841-17850. [CrossRef] [PubMed]

34. Wijten, P.; van Holten, T.; Woo, L.L.; Bleijerveld, O.B.; Roest, M.; Heck, A.J.; Scholten, A. High precision platelet releasate definition by quantitative reversed protein profiling-Brief report. Arterioscler. Thromb. Vasc. Biol. 2013, 33, 1635-1638. [CrossRef] [PubMed]

35. Mackey, J.R.; Mani, R.S.; Selner, M.; Mowles, D.; Young, J.D.; Belt, J.A.; Crawford, C.R.; Cass, C.E. Functional nucleoside transporters are required for gemcitabine influx and manifestation of toxicity in cancer cell lines. Cancer Res. 1998, 58, 4349-4357. [PubMed]

36. Weizman, N.; Krelin, Y.; Shabtay-Orbach, A.; Amit, M.; Binenbaum, Y.; Wong, R.J.; Gil, Z. Macrophages mediate gemcitabine resistance of pancreatic adenocarcinoma by upregulating cytidine deaminase. Oncogene 2014, 33, 3812. [CrossRef] [PubMed]

37. White, N.; Burnstock, G. P2 receptors and cancer. Trends Pharmacol. Sci. 2006, 27, 211-217. [CrossRef] [PubMed]

38. Giannuzzo, A.; Saccomano, M.; Napp, J.; Ellegaard, M.; Alves, F.; Novak, I. Targeting of the P2X7 receptor in pancreatic cancer and stellate cells. Int. J. Cancer 2016, 139, 2540-2552. [CrossRef] [PubMed]

39. Li, W.H.; Qiu, Y.; Zhang, H.Q.; Liu, Y.; You, J.F.; Tian, X.X.; Fang, W.G. P2Y2 receptor promotes cell invasion and metastasis in prostate cancer cells. Br. J. Cancer 2013, 109, 1666-1675. [CrossRef] [PubMed]

40. Qiu, Y.; Li, W.-H.; Zhang, H.-Q.; Liu, Y.; Tian, X.-X.; Fang, W.-G. P2X7 mediates ATP-driven invasiveness in prostate cancer cells. PLoS ONE 2014, 9, e114371. [CrossRef] [PubMed]

41. Cedervall, J.; Zhang, Y.; Ringvall, M.; Thulin, A.; Moustakas, A.; Jahnen-Dechent, W.; Siegbahn, A.; Olsson, A.K. Hrg regulates tumor progression, epithelial to mesenchymal transition and metastasis via platelet-induced signaling in the pre-tumorigenic microenvironment. Angiogenesis 2013, 16, 889-902. [CrossRef] [PubMed]

42. Schumacher, D.; Strilic, B.; Sivaraj, K.K.; Wettschureck, N.; Offermanns, S. Platelet-derived nucleotides promote tumor-cell transendothelial migration and metastasis via P2Y2 receptor. Cancer Cell 2013, 24, 130-137. [CrossRef] [PubMed]

43. Mitrugno, A.; Sylman, J.L.; Ngo, A.T.; Pang, J.; Sears, R.C.; Williams, C.; McCarty, O.J. Aspirin therapy reduces the ability of platelets to promote colon and pancreatic cancer cell proliferation: Implications for the oncoprotein c-MYC. Am. J. Physiol. Cell Physiol. 2016. [CrossRef] [PubMed]

44. Radziwon-Balicka, A.; Medina, C.; O’Driscoll, L.; Treumann, A.; Bazou, D.; Inkielewicz-Stepniak, I.; Radomski, A.; Jow, H.; Radomski, M.W. Platelets increase survival of adenocarcinoma cells challenged with anticancer drugs: Mechanisms and implications for chemoresistance. Br. J. Pharmacol. 2012, 167, 787-804. [CrossRef] [PubMed] 
45. Saito, H.; Fushida, S.; Miyashita, T.; Oyama, K.; Yamaguchi, T.; Tsukada, T.; Kinoshita, J.; Tajima, H.; Ninomiya, I.; Ohta, T. Potential of extravasated platelet aggregation as a surrogate marker for overall survival in patients with advanced gastric cancer treated with preoperative docetaxel, cisplatin and S-1: A retrospective observational study. BMC Cancer 2017, 17, 294. [CrossRef] [PubMed]

46. Cho, M.S.; Bottsford-Miller, J.; Vasquez, H.G.; Stone, R.; Zand, B.; Kroll, M.H.; Sood, A.K.; Afshar-Kharghan, V. Platelets increase the proliferation of ovarian cancer cells. Blood 2012, 120, 4869-4872. [CrossRef] [PubMed]

47. Carr, B.I.; Cavallini, A.; D'Alessandro, R.; Refolo, M.G.; Lippolis, C.; Mazzocca, A.; Messa, C. Platelet extracts induce growth, migration and invasion in human hepatocellular carcinoma in vitro. BMC Cancer 2014, 14, 43. [CrossRef] [PubMed]

48. Fahy, B.N.; Schlieman, M.; Virudachalam, S.; Bold, R.J. AKT inhibition is associated with chemosensitisation in the pancreatic cancer cell line MIA-PaCa-2. Br. J. Cancer 2003, 89, 391-397. [CrossRef] [PubMed]

49. Ng, S.S.W.; Tsao, M.S.; Nicklee, T.; Hedley, D.W. Wortmannin Inhibits PKB/Akt Phosphorylation and Promotes Gemeitabine Antitumor Activity in Orthotopic Human Pancreatic Cancer Xenografts in Immunodeficient Mice. Clin. Cancer Res. 2001, 7, 3269-3275. [PubMed]

50. Wang, M.; Lu, X.; Dong, X.; Hao, F.; Liu, Z.; Ni, G.; Chen, D. pERK1/2 silencing sensitizes pancreatic cancer BXPC-3 cell to gemcitabine-induced apoptosis via regulating Bax and Bcl-2 expression. World J. Surg. Oncol. 2015, 13, 66. [CrossRef] [PubMed]

51. Zheng, C.; Jiao, X.; Jiang, Y.; Sun, S. ERK1/2 activity contributes to gemcitabine resistance in pancreatic cancer cells. J. Int. Med. Res. 2013, 41, 300-306. [CrossRef] [PubMed]

52. Takemoto, A.; Okitaka, M.; Takagi, S.; Takami, M.; Sato, S.; Nishio, M.; Okumura, S.; Fujita, N. A critical role of platelet TGF- $\beta$ release in podoplanin-mediated tumour invasion and metastasis. Sci. Rep. 2017, 7, 42186. [CrossRef] [PubMed]

53. Xu, J.; Lamouille, S.; Derynck, R. TGF- $\beta$-induced epithelial to mesenchymal transition. Cell Res. 2009, 19, 156-172. [CrossRef] [PubMed]

54. De Caestecker, M.P.; Piek, E.; Roberts, A.B. Role of transforming growth factor- $\beta$ signaling in cancer. J. Natl. Cancer Inst. 2000, 92, 1388-1402. [CrossRef] [PubMed]

55. Nakao, A.; Imamura, T.; Souchelnytskyi, S.; Kawabata, M.; Ishisaki, A.; Oeda, E.; Tamaki, K.; Hanai, J.; Heldin, C.H.; Miyazono, K.; et al. TGF- $\beta$ receptor-mediated signalling through Smad2, Smad3 and Smad4. EMBO J. 1997, 16, 5353-5362. [CrossRef] [PubMed]

56. Truty, M.J.; Urrutia, R. Basics of TGF- $\beta$ and pancreatic cancer. Pancreatology 2007, 7, 423-435. [CrossRef] [PubMed]

57. Joseph, M.J.; Dangi-Garimella, S.; Shields, M.A.; Diamond, M.E.; Sun, L.; Koblinski, J.E.; Munshi, H.G. Slug is a downstream mediator of transforming growth factor- $\beta 1$-induced matrix metalloproteinase- 9 expression and invasion of oral cancer cells. J. Cell. Biochem. 2009, 108, 726-736. [CrossRef] [PubMed]

58. Hino, M.; Kamo, M.; Saito, D.; Kyakumoto, S.; Shibata, T.; Mizuki, H.; Ishisaki, A. Transforming growth factor- $\beta 1$ induces invasion ability of HSC-4 human oral squamous cell carcinoma cells through the Slug/Wnt-5b/MMP-10 signalling axis. J. Biochem. 2016, 159, 631-640. [CrossRef] [PubMed]

59. Shi, Z.M.; Wang, L.; Shen, H.; Jiang, C.F.; Ge, X.; Li, D.M.; Wen, Y.Y.; Sun, H.R.; Pan, M.H.; Li, W.; et al. Downregulation of miR-218 contributes to epithelial-mesenchymal transition and tumor metastasis in lung cancer by targeting Slug/Zeb2 signaling. Oncogene 2017, 36, 2577-2588. [CrossRef] [PubMed]

60. Subramanian, G.; Schwarz, R.E.; Higgins, L.; McEnroe, G.; Chakravarty, S.; Dugar, S.; Reiss, M. Targeting endogenous transforming growth factor $\beta$ receptor signaling in SMAD4-deficient human pancreatic carcinoma cells inhibits their invasive phenotype1. Cancer Res. 2004, 64, 5200-5211. [CrossRef] [PubMed]

61. Zhao, S.; Ammanamanchi, S.; Brattain, M.; Cao, L.; Thangasamy, A.; Wang, J.; Freeman, J.W. Smad4-dependent TGF- $\beta$ signaling suppresses RON receptor tyrosine kinase-dependent motility and invasion of pancreatic cancer cells. J. Biol. Chem. 2008, 283, 11293-11301. [CrossRef] [PubMed]

62. Su, H.T.; Weng, C.C.; Hsiao, P.J.; Chen, L.H.; Kuo, T.L.; Chen, Y.W.; Kuo, K.K.; Cheng, K.H. Stem cell marker nestin is critical for TGF- $\beta$ 1-mediated tumor progression in pancreatic cancer. Mol. Cancer Res. 2013, 11, 768-779. [CrossRef] [PubMed]

63. Zhang, X.Y.; Cao, J.X.; Pei, Y.J.; Zhang, J.Y.; Wang, Q.Y. Smad4 inhibits cell migration via suppression of JNK activity in human pancreatic carcinoma PANC-1 cells. Oncol. Lett. 2016, 11, 3465-3470. [CrossRef] [PubMed] 
64. Chen, Y.W.; Hsiao, P.J.; Weng, C.C.; Kuo, K.K.; Kuo, T.L.; Wu, D.C.; Hung, W.C.; Cheng, K.H. SMAD4 loss triggers the phenotypic changes of pancreatic ductal adenocarcinoma cells. BMC Cancer 2014, 14, 181. [CrossRef] [PubMed]

65. Marechal, R.; Mackey, J.R.; Lai, R.; Demetter, P.; Peeters, M.; Polus, M.; Cass, C.E.; Salmon, I.; Deviere, J.; Van Laethem, J.L. Deoxycitidine kinase is associated with prolonged survival after adjuvant gemcitabine for resected pancreatic adenocarcinoma. Cancer 2010, 116, 5200-5206. [CrossRef] [PubMed]

66. Pires, B.R.; Mencalha, A.L.; Ferreira, G.M.; de Souza, W.F.; Morgado-Diaz, J.A.; Maia, A.M.; Correa, S.; Abdelhay, E.S. NF-kB is involved in the regulation of EMT genes in breast cancer cells. PLoS ONE 2017, 12, e0169622. [CrossRef] [PubMed]

67. Zhang, Y.; Lapidus, R.G.; Liu, P.; Choi, E.Y.; Adediran, S.; Hussain, A.; Wang, X.; Liu, X.; Dan, H.C.

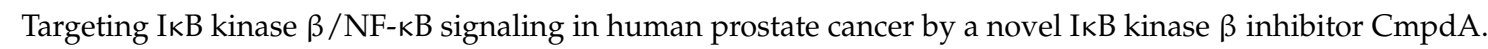
Mol. Cancer Ther. 2016. [CrossRef] [PubMed]

68. Zhou, Y.; Tozzi, F.; Chen, J.; Fan, F.; Xia, L.; Wang, J.; Gao, G.; Zhang, A.; Xia, X.; Brasher, H.; et al. Intracellular ATP levels are a pivotal determinant of chemoresistance in colon cancer cells. Cancer Res. 2012, 72, 304-314. [CrossRef] [PubMed]

69. Fang, M.; Shen, Z.; Huang, S.; Zhao, L.; Chen, S.; Mak, T.W.; Wang, X. The ER UDPase ENTPD5 promotes protein N-glycosylation, the Warburg effect, and proliferation in the PTEN pathway. Cell 2010, 143, 711-724. [CrossRef] [PubMed]

70. Ko, T.; An, H.J.; Ji, Y.G.; Kim, O.J.; Lee, D.H. P2Y receptors regulate proliferation of human pancreatic duct epithelial cells. Pancreas 2012, 41, 797-803. [CrossRef] [PubMed]

71. Giannuzzo, A.; Pedersen, S.F.; Novak, I. The P2X7 receptor regulates cell survival, migration and invasion of pancreatic ductal adenocarcinoma cells. Mol. Cancer 2015, 14, 203. [CrossRef] [PubMed]

72. Uhlen, M.; Zhang, C.; Lee, S.; Sjostedt, E.; Fagerberg, L.; Bidkhori, G.; Benfeitas, R.; Arif, M.; Liu, Z.; Edfors, F.; et al. A pathology atlas of the human cancer transcriptome. Science 2017, 357. [CrossRef] [PubMed]

73. Uhlén, M.; Fagerberg, L.; Hallström, B.M.; Lindskog, C.; Oksvold, P.; Mardinoglu, A.; Sivertsson, Å.; Kampf, C.; Sjöstedt, E.; Asplund, A.; et al. Tissue-based map of the human proteome. Science 2015, 347. [CrossRef] [PubMed]

74. Dorsam, R.T.; Kunapuli, S.P. Central role of the P2Y12 receptor in platelet activation. J. Clin. Investig. 2004, 113, 340-345. [CrossRef] [PubMed]

75. Hollopeter, G.; Jantzen, H.M.; Vincent, D.; Li, G.; England, L.; Ramakrishnan, V.; Yang, R.B.; Nurden, P.; Nurden, A.; Julius, D.; et al. Identification of the platelet ADP receptor targeted by antithrombotic drugs. Nature 2001, 409, 202-207. [CrossRef] [PubMed]

76. Zhang, F.L.; Luo, L.; Gustafson, E.; Lachowicz, J.; Smith, M.; Qiao, X.; Liu, Y.H.; Chen, G.; Pramanik, B.; Laz, T.M.; et al. ADP is the cognate ligand for the orphan G protein-coupled receptor SP1999. J. Biol. Chem. 2001, 276, 8608-8615. [CrossRef] [PubMed]

77. Satonaka, H.; Nagata, D.; Takahashi, M.; Kiyosue, A.; Myojo, M.; Fujita, D.; Ishimitsu, T.; Nagano, T.; Nagai, R.; Hirata, Y. Involvement of P2Y12 receptor in vascular smooth muscle inflammatory changes via MCP-1 upregulation and monocyte adhesion. Am. J. Physiol. 2015, 308, H853-H861.

78. Rauch, B.H.; Rosenkranz, A.C.; Ermler, S.; Bohm, A.; Driessen, J.; Fischer, J.W.; Sugidachi, A.; Jakubowski, J.A.; Schror, K. Regulation of functionally active P2Y12 ADP receptors by thrombin in human smooth muscle cells and the presence of P2Y12 in carotid artery lesions. Arterioscler. Thromb. Vasc. Biol. 2010, 30, $2434-2442$. [CrossRef] [PubMed]

79. Lugo-Garcia, L.; Nadal, B.; Gomis, R.; Petit, P.; Gross, R.; Lajoix, A.D. Human pancreatic islets express the purinergic P2Y11 and P2Y12 receptors. Horm. Metab. Res. 2008, 40, 827-830. [CrossRef] [PubMed]

80. Armstrong, D.; Summers, C.; Ewart, L.; Nylander, S.; Sidaway, J.E.; van Giezen, J.J. Characterization of the adenosine pharmacology of ticagrelor reveals therapeutically relevant inhibition of equilibrative nucleoside transporter 1. J. Cardiovasc. Pharmacol. Ther. 2014, 19, 209-219. [CrossRef] [PubMed]

81. Cattaneo, M.; Schulz, R.; Nylander, S. Adenosine-mediated effects of ticagrelor: Evidence and potential clinical relevance. J. Am. Coll. Cardiol. 2014, 63, 2503-2509. [CrossRef] [PubMed]

82. Mediavilla-Varela, M.; Luddy, K.; Noyes, D.; Khalil, F.K.; Neuger, A.M.; Soliman, H.; Antonia, S.J. Antagonism of adenosine A2A receptor expressed by lung adenocarcinoma tumor cells and cancer associated fibroblasts inhibits their growth. Cancer Biol. Ther. 2013, 14, 860-868. [CrossRef] [PubMed] 
83. U.S. Food and Drug Administration. Pharmacology Review(s). Available online: https:/ /www.accessdata. fda.gov/drugsatfda_docs/nda/2011/022433Orig1s000PharmR.pdf (accessed on 23 October 2017).

84. Torres, A.; Vargas, Y.; Uribe, D.; Jaramillo, C.; Gleisner, A.; Salazar-Onfray, F.; Lopez, M.N.; Melo, R.; Oyarzun, C.; San Martin, R.; et al. Adenosine A3 receptor elicits chemoresistance mediated by multiple resistance-associated protein-1 in human glioblastoma stem-like cells. Oncotarget 2016, 7, 67373-67386. [CrossRef] [PubMed]

85. Booth, L.; Roberts, J.L.; Cruickshanks, N.; Conley, A.; Durrant, D.E.; Das, A.; Fisher, P.B.; Kukreja, R.C.; Grant, S.; Poklepovic, A.; et al. Phosphodiesterase 5 inhibitors enhance chemotherapy killing in gastrointestinal/genitourinary cancer cells. Mol. Pharmacol. 2014, 85, 408-419. [CrossRef] [PubMed]

86. Pellegatti, P.; Raffaghello, L.; Bianchi, G.; Piccardi, F.; Pistoia, V.; Di Virgilio, F. Increased level of extracellular ATP at tumor sites: In vivo imaging with plasma membrane luciferase. PLoS ONE 2008, 3, e2599. [CrossRef] [PubMed]

87. Yegutkin, G.G.; Marttila-Ichihara, F.; Karikoski, M.; Niemelä, J.; Laurila, J.P.; Elima, K.; Jalkanen, S.; Salmi, M. Altered purinergic signaling in CD73-deficient mice inhibits tumor progression. Eur. J. Immunol. 2011, 41, 1231-1241. [CrossRef] [PubMed]

88. Di Virgilio, F. Purines, purinergic receptors, and cancer. Cancer Res. 2012, 72, 5441-5447. [CrossRef] [PubMed]

89. Radomski, M.; Moncada, S. An improved method for washing of human platelets with prostacyclin. Thromb. Res. 1983, 30, 383-389. [CrossRef]

90. Ahmed, S.A.; Gogal, R.M., Jr.; Walsh, J.E. A new rapid and simple non-radioactive assay to monitor and determine the proliferation of lymphocytes: An alternative to $\left[{ }^{3} \mathrm{H}\right]$ thymidine incorporation assay. J. Immunol. Methods 1994, 170, 211-224. [CrossRef]

91. Wen, F.; Shen, A.; Choi, A.; Gerner, E.W.; Shi, J. Extracellular DNA in pancreatic cancer promotes cell invasion and metastasis. Cancer Res. 2013, 73, 4256-4266. [CrossRef] [PubMed]

(C) 2017 by the authors. Licensee MDPI, Basel, Switzerland. This article is an open access article distributed under the terms and conditions of the Creative Commons Attribution (CC BY) license (http:/ / creativecommons.org/licenses/by/4.0/). 